\title{
Serum copper levels in benign and malignant thyroid diseases
}

\author{
Kosova $\mathrm{F}^{1}$, Cetin $\mathrm{B}^{2}$, Akinci $\mathrm{M}^{3}$, Aslan $\mathrm{S}^{2}$, Seki $\mathrm{A}^{2}$, Pirhan $\mathrm{Y}^{2}$, Ari $\mathrm{Z}^{4}$ \\ Celal Bayar University, Department of Biochemistry, Manisa, Turkey. seboaslan@yahoo.co.uk
}

\begin{abstract}
Objective: To examine the changes in serum copper $(\mathrm{Cu})$ levels in benign and malignant thyroid disease in humans.

Background: Thyroid hormones influence the metabolism of trace elements including copper.

Methods: 47 papillary thyroid cancer and 43 benign multinodular goitre patients who underwent total thyroidectomy and 37 healthy control subjects were included into this study. All of the patients and controls were females. Serum $\mathrm{Cu}$ levels were detected with atomic absorption spectrophotometer.

Results: In the papillary thyroid cancer group serum level of $\mathrm{Cu}$ was $131.61 \pm 33.9 \mu \mathrm{g} / \mathrm{dL}$ before surgery and $120.81 \pm 30.4 \mu \mathrm{g} / \mathrm{dL}$ after 20 days from surgery. In the benign group serum $\mathrm{Cu}$ level was $84.75 \pm 12.1$ $\mu \mathrm{g} / \mathrm{dL}$ and $68.01 \pm 9.4 \mu \mathrm{g} / \mathrm{dL}$ postoperatively. These results were compared to healthy control's value of $105.87 \pm 10.68 \mu \mathrm{g} / \mathrm{dL}$. In the papillary thyroid cancer group pre- and postoperative serum Cu level was significantly higher when compared to control group $(p<0.05)$. Postoperative serum $\mathrm{Cu}$ level significantly decreased when compared to pre-operative level $(p<0.05)$, in which, it was still higher than the control $(p<0.05)$. In the benign group pre- and postoperative serum Cu level was significantly lower than in the control group $(p<0.05)$.Postoperative serum $\mathrm{Cu}$ level significantly decreased when compared to pre-operative level in the benign group $(p<0.05)$.

Conclusion: This is a pioneer study to examine serum $\mathrm{Cu}$ level in benign and malignant thyroid patients compared to controls. In our small groups serum Cu levels increased in malignant thyroid patients and decreased in the benign group (Tab. 1, Ref. 18). Full Text in PDF www.elis.sk.

Key words: copper, papillary cancer, thyroid cancer, multinoduler goitre.
\end{abstract}

Trace elements are essential micro-nutrients both for humans and other organisms. They are crucial for many physiological processes and are involved in many pathologic changes in tissues (1). Thyroid hormones influence the metabolism of trace elements including copper $(\mathrm{Cu})(2)$. $\mathrm{Cu}$ is important for the activity of the enzyme superoxide dismutase (SOD). Changes in the activity of this enzyme are consistent with the $\mathrm{Cu}$ serum levels (3). $\mathrm{Cu}$ was shown to be essential for cell division both in normal and cancerous tissue $(4,5)$. Although copper is an essential element for human and animals, a high concentration of $\mathrm{Cu}$ (above normal) could induce growth proliferation and cancer by damaging DNA with toxic free hydroxyl radicals (6).

The present study was undertaken to investigate correlation of $\mathrm{Cu}$ serum levels in benign and malign thyroid diseases before and after surgery compared to controls.

\section{Materials and methods}

This is an age-and sex-matched case-control study, conducted at the Department of Medical Biochemistry of Celal Bayar Univer-

${ }^{1}$ Celal Bayar University, Department of Biochemistry, Manisa, Turkey, ${ }^{2}$ Ankara Oncology Hospital, Department of General Surgery, Ankara, Turkey, ${ }^{3}$ Diskapi Yildirim Beyazit Hospital, Department of General Surgery, Ankara, Turkey, and ${ }^{4}$ Celal Bayar University, School of Medicine, Department of Biochemistry and Clinical Biochemistry , Manisa, Turkey

Address for correspondence: S. Aslan, Kardelen Mah. Batipark Konutlari, 2040 sk. I Blok Daire: 2, Batikent/Y.mahalle, Ankara, Turkey. sity of Medicine and the Department of General Surgery of Ankara Oncology Hospital, Ankara, Turkey. The study was approved by the hospital Ethical committee. All the patients and the volunteers involved in the study have given informed consent.

\section{Patients}

Recruitment of subjects was performed by convenience sampling at outpatient General Surgery Clinic of Oncology Hospital, Turkey by trained physicians. 47 papillary thyroid cancer patients, 43 benign multinodular goitre patients and 37 healthy control subjects with normal thyroid function tests were included in this study. These patients were female gender presented with multinodular goiter in thyroid ultrasonography and were grouped as malignant and benign after total thyroidectomy according to pathologic examination. Occult papillary carcinoma was excluded from the study. As patients with follicular carcinoma and medullar carcinoma of the thyroid were rare, for statistical analysis only patients with papillary morphology were included into the study. Total thyroidectomy was performed after which they came to a control visit on the twentieth postoperative day and they were not on the replacement therapy. The controls were age and sex matched healthy volunteers.

\section{Assay}

Blood samples were kept at $-70^{\circ} \mathrm{C}$ until analysis. All samples from each patient were run in the same assay.

Serum thyroid hormones were measured by radioimmunoassay kits (TOSOH). 
For serum levels of $\mathrm{Cu}$, serum is deproteinized with trichloroasetic acid and the supernatant analyzed by atomic absorption spectrophotometer at a wavelenght of $324.7 \mathrm{~nm}$ respectively, according to the method of Unicam Atomic Absorption Spectrophotometry manual.

\section{Statistics}

Non-parametric methods were used in the cross-sectional analysis of biomedical data (Mann-Whitney U test). Two -tailed probability (p) values were calculated and statistical significance was defined as $\mathrm{p}<0.05$. All analyses were performed by statistical software SPSS 10.0.

\section{Results}

47 papillary thyroid cancer (mean age $41 \pm 13$ years) and 43 benign multinodular goitre patients (mean age $39 \pm 14$ years) who had undergone total thyroidectomy and 37 healthy control subjects (mean age $42 \pm 13$ years) were included in this study. All of the patients and controls were female. Age, gender (all of the subjects were female), menopausal status were not significantly different between the benign and malignant thyroid patients and the control group. The thyroid hormone levels were within normal limits in all groups. No patient in the study had radiologically and clinically pathologic lymph nodes and neck dissection was not performed. And there was no patient who had got metastatic lymph node which was reported pathologically after total thyroidectomy.

The serum copper level in healthy control group was 105.87$10.68 \mu \mathrm{g} / \mathrm{dL}$ and $131.61-33,9 \mu \mathrm{g} / \mathrm{dL}$ and $120.81-30.4 \mu \mathrm{g} / \mathrm{dL}$ in thyroid cancer patients pre and post operatively. $\mathrm{Cu}$ levels of thyroid cancer patients pre-operatively was found to be higher than those in age-matched controls $(\mathrm{p}<0.05)$. Post-operatively $\mathrm{Cu}$ levels were also significantly higher compared to control $(\mathrm{p}<0.05)$ but significantly lower than pre-operative serum $\mathrm{Cu}$ levels indicating a decrease in $\mathrm{Cu}$ serum levels after surgery $(\mathrm{p}<0.05)$. In the benign group serum pre and post operative $\mathrm{Cu}$ levels were $84.75 \pm 12.1 \mu \mathrm{g} / \mathrm{dL}$ and $68.01 \pm 9.4$ $\mu \mathrm{g} / \mathrm{dL}$. These results were compared to control value of $105.87 \pm 10.68$ $\mu \mathrm{g} / \mathrm{dL}$. In the benign group pre-and postoperative serum $\mathrm{Cu}$ levels were significantly lower than in the control group $(\mathrm{p}<0.05)$. Postoperative serum $\mathrm{Cu}$ levels significantly decreased compared to those of pre-operative levels for the benign group $(\mathrm{p}<0.05)$ (Tab. 1).

\section{Discussion}

The concentration of trace elements in the thyroid gland is higher than in other tissues (7) and it has been shown that the thy-

\section{Tab. 1. Cooper $(\mathrm{Cu})$ levels in thyroid cancer.}

\begin{tabular}{ll}
\hline Group & Cu Levels $(\mu \mathrm{g} / \mathrm{dL})$ \\
\hline Control & $105.87 \pm 10.68$ \\
Malignant prethyroidectomy & $131.61 \pm 33.9^{*}$ \\
Malignant postthyroidectomy & $120.81 \pm 30.4^{*} \#$ \\
Benign prethyroidectomy & $84.75 \pm 12.1^{*}$ \\
Benign postthyroidectomy & $68.01 \pm 9.4^{* \#}$ \\
\hline * p $<0.05$ compared to control group, \# $\mathrm{p}<0.05$ compared to prethyroidectomy levels
\end{tabular}

roid hormones do influence the metabolism of these elements (2, $8-10)$. Furthermore, changes in these elements were associated with development of goiter and other thyroid pathologies including cancer (7). Trace elements are essential micro-nutrients both for humans and other organisms. They are crucial for many physiological processes and are involved in many pathologic changes in tissues (1). On the other hand, it is well known that either an excess or a deficiency of certain trace metals can lead to biological disorders. Uda et al observed that the deficiency or excess of trace elements concentrations in cancerous tissues of different organs may be different (11). In the literature, it is described that trace element concentrations of healthy adult thyroid glands were not dependent on sex or age (12). In our series all of the patients and healthy controls were females and there was no statistical difference between the groups $(\mathrm{p}>0.05)$.

Copper being a cofactor of some metalloenzymes is required for the maintenance of optimal health, normal cellular homeostasis, optimum function of the immune system and the structure and function of skeletal, cardiovascular and nervous systems (10). Copper is helping to form haemoglobin in the blood facilitating the absorption and use of iron so that red blood cells can transport oxygen to tissues and assisting in the regulation of blood pressure and heart rate (6).

$\mathrm{Cu}$ is essential for the antioxidant function of $\mathrm{Cu} / \mathrm{Zn}-\mathrm{SOD}$, although it may act as a prooxidant towards lipids. $\mathrm{Cu}$ deficiency directly affects the function of cuproproteins with antioxidant functions, such as $\mathrm{Cu} / \mathrm{Zn}$-SOD, ceruloplasmin, and metallohtionein process, and indirectly affects GSH peroxidase activity (13). As seen $\mathrm{Cu}$ is important for the activity of the enzyme superoxide dismutase (SOD). Changes in the activity of this enzyme are consistent with the $\mathrm{Cu}$ serum levels (3). It was shown that thyroid hormones influence the metabolism of trace elements including $\mathrm{Cu}$ (2). $\mathrm{Cu}$ was shown to be essential for cell division both in normal and cancerous tissue $(4,5)$. In extracellular environment, $\mathrm{H}_{2} \mathrm{O}_{2}$ reacts with $\mathrm{Cu}$, generating highly reactive hydroxyl radicals, which can react with macromolecules in the vicinity and could cause damage (9). Although copper is an essential element for human and animals, a high concentration of $\mathrm{Cu}$ (above normal) could induce growth proliferation and cancer by damaging DNA with toxic free hydroxyl radicals (6).

Thyroid hormones are associated with oxidative and antioxidative status of the organism. Depression of metabolism by hypothyroidism has been reported to decrease oxidant production and thus protect tissues against oxidant damage. However, data on the oxidative status of hypothyroidism are limited and controversial (13) Zhang et al suggested that homeostasis of metal ions in both serum and erythrocytes could be more or less influenced by the altered thyroid hormones, and they reported that serum $\mathrm{Cu}$ and $\mathrm{Zn}$ exhibited significantly positive correlation with $\mathrm{T} 3$ and T4 (14). Alturfan et al also found decreased T3, T4 and $\mathrm{Cu}, \mathrm{Zn}$ levels in MMI-induced hyperthroid rats (13). These results may illustrate the protective effect of these trace elements as cofactors of antioxidant enzymes in limiting oxidative stres.

The present study was undertaken to investigate any correlation of $\mathrm{Cu}$ serum levels in thyroid cancer patients before and after 
surgery. In this series $\mathrm{Cu}$ serum levels increased significantly in thyroid papillary cancer patients when compared to both normal control group and to post-operative levels. After excision of the cancerous thyroid tissue $\mathrm{Cu}$ serum levels dropped significantly but were still higher than in the control group $(\mathrm{p}<0.005)$. The patients came to a control visit on the postoperative day 20 and they were not on replacement therapy.The post thyroidectomy $\mathrm{Cu}$ level decrease might be influenced by hypothyroidism but it must be remembered that $\mathrm{Cu}$ levels were low in benign group and high in the malignant. In spite of the decrease it was still high in the malignant group after thyroidectomy. So decreasing levels could not be attributed only to the hypothyroidism. Postoperative 20 days may not be enough to return to the normal values and long term follow-up ia necessray

The elevation of serum levels of $\mathrm{Cu}$ in papillary thyroid cancer patients may be related to disease condition as thyroid hormones influence the metabolism of $\mathrm{Cu}$ or elevation of $\mathrm{Cu}$ from another causes may be the reason of the thyroid cancer, as in extracellular environment, $\mathrm{H}_{2} \mathrm{O}_{2}$ reacts with $\mathrm{Cu}$, generating highly reactive hydroxyl radicals, which can react with macromolecules in the vicinity and could cause damage. In this study postoperatively serum levels decreased but were still higher than the normal control which may be much more the indication that serum $\mathrm{Cu}$ elevation is a result of the disease condition more than being a reason. Serum levels of $\mathrm{Cu}$ were not investigated in occult thyroid carinoma patients and also in follicular, medullar or anaplastic cancers of the thyroid. Levels of $\mathrm{Cu}$ in this patient group might give some idea. Some of the other studies show normal serum $\mathrm{Cu}$ levels of thyroid cancer patients and an increase after surgery (15). In our series serum $\mathrm{Cu}$ levels of benign thyroid patients were lower than controls both before and after thyroidectomy. Besides post thyroidectomy levels were lower than prethyroidectomy levels for the benign group which could be also suggest that decreased serum $\mathrm{Cu}$ levels were a result of the disease condition more than being a reason. In opposite to our results Reddy et al (16) have reported lower levels of $\mathrm{Cu}$ in the tissue of cancerous thyroid than in normal thyroid tissue and like our results (our results are reflecting serum levels), much lower levels of $\mathrm{Cu}$ in the tissue of thyroid adenoma. Other authors have estimated the concentration rates of $\mathrm{Cu} / \mathrm{Zn}$ in the cancerous thyroid tumour were significantly higher than in the normal and other thyroid disease $(12,17,18)$.

In summary, the increase of serum levels of $\mathrm{Cu}$ in cancer patients and low serum levels of $\mathrm{Cu}$ in benign thyroid disease may be linked to the disease condition. This is a pioneer study and patient numbers are low to reach any conclusion.Larger series are still needed. Also serum levels of $\mathrm{Cu}$ must be still investigated in occult thyroid carcinoma. If our results could be confirmed in further studies, serum $\mathrm{Cu}$ levels would be promising in differentiating malignant from benign disease in thyroid patients.

\section{References}

1. Margoloth EJ, Schenker JG, Chevion M. Cooper and zinc levels in normal and malignant tissues cancer 1983; 52: 868-872.

2. Irani K et al. Mitogenic signalling mediated by oxidants in Ras- transformed fibroblasts, Science 1997; 275: 1649-1652.

3. Hikasoka T, Miyagowa S, Yakozowa T et al. Effects of the endocrine function on the trace metal ( magnesium, zinc, and cooper) in serum. Folio Endocrinol Jap 1982; 58: 502.

4. Leblandel G, Allain P. Effects of thyroparathyroidectomy and of thyroxine and calcitonin on tissue distribution of twelve elements in the rat. Biol Trace Element Res 1989; 19: 171-183.

5. Swaminothan R, Segall NH, Champion C et al. Red blood cell composition in thyroid disease. Lancet 1976; 2: 1382-1387.

6. Theophanides T, Anastassopoulou J. Copper and carcinogenesis. Crit Rev Oncol Hematol 2002; 42 (1): 57-64.

7. Kosova F, Cetin B, Aslan S, Ari Z, Sepici A, Atlan N, Cetin A. Adxanced oxidation protein products, ferrous oxidation in xylenol orange and malondiaaldehyde levels in thyroid cancer. Ann Surg Oncol 2007; 14 (9): 2616-2620.

8. Karbownik M, Lewnski A. The role of oxidative stress in physiological and pathological processes in the thyroid gland; possible involvement in pineal-thyroid interactions. Neuro Endocrinol Lett 2003; 24 (5): 293-303.

9. Aust SD, Morehouse LA, Thomas CE. Role of metals in oxygen radical reactions. J Free Radic Biol Med 1985; 1: 3-25.

10. Panemangalore M, Bebe FN. Biol Trace Element Res 1996; 55: 111.

11. Uda M, Maeda K, Sasa Y, Kusuyama H, Yokodo Y. An attempt to diagnose cancer by PIXE. Nucl Instr Meth B 1987; 22 (1-3): 184-187.

12. Yaman M, Akdeniz I. Sensitivity enhancment in flame atomic absorption spectrometry for determination of copper in human thyroid tissues. Anal Sci 2004; 20 (9): 1363-1366.

13. Alturfan AA, Zengin E, Dariyerli N, Alturfan EE, Gümüstas KK, Aytac E, Aslan M, Balkis N, Aksu A, Yigit G, Uslu E, Kokoglu E. Investigation of Zinc and Copper Levels in Methimazole-Induced Hypothyroidism: Relation with the Oxidant-Antioxidant Status. Folia Biol (Praha) 2007; 53: 183-188.

14. Zhang F, Liu N, Wang X, Zhu L, Chai Z. Study of trace elements in blood of thyroid disorder subjects before and after 131I therapy. Biol Trace Elem Res 2004; 97: 125-134.

15. Al-Sayer H, Mathew TC, Asfar S, Khourshed M et al. Serum changes in trace elements during thyroid cancers. Mol Cell Biochem 2004; 260: $1-5$.

16. Reddy SB, Charles MJ, Kumar MR, Reddy C, Anjancyulu GJ et al. Nucl Instr Meth Phys Res B 2002; 196: 333.

17. Iwase K, Nagasaka A, Kato K, Ohtani S et al. Acta Endocrinol 1993; 129 (6): 573.

18. Kucharzewski M, Braziewicz J, Majewska U et al. Biol Trace Element Res 2003; 93: 9. 